Electronics 2014, 3, 112-121; doi:10.3390/electronics3010112

ISSN 2079-9292

www.mdpi.com/journal/electronics

\title{
Article
}

\section{Effects of Germanium Tetrabromide Addition to Zinc Tetraphenyl Porphyrin / Fullerene Bulk Heterojunction Solar Cells}

\author{
Atsushi Suzuki *, Kenta Nishimura and Takeo Oku \\ Department of Materials Science, The University of Shiga Prefecture, 2500 Hassaka, Hikone, \\ Shiga 522-8533, Japan; E-Mails: step-by-step623@docomo.ne.jp (K.N.); oku@ mat.usp.ac.jp (T.O.) \\ * Author to whom correspondence should be addressed; E-Mail: suzuki@ mat.usp.ac.jp; \\ Tel.: +81-749-28-8369, Fax: +81-749-28-8591.
}

Received: 15 January 2014; in revised form: 1 February 2014 / Accepted: 24 February 2014 / Published: 4 March 2014

\begin{abstract}
The effects of germanium tetrabromide addition to tetraphenyl porphyrin zinc $(\mathrm{Zn}-\mathrm{TPP}) /$ fullerene $\left(\mathrm{C}_{60}\right)$ bulk heterojunction solar cells were characterized. The light-induced charge separation and charge transfer were investigated by current density and optical absorption. Addition of germanium tetrabromide inserted into active layer of $\mathrm{Zn}-\mathrm{TPP} / \mathrm{C}_{60}$ as bulk heterojunction had a positive effect on the photovoltaic and optical properties. The photovoltaic mechanism of the solar cells was discussed by experimental results. The photovoltaic performance was due to light-induced exciton promoted by insert of $\mathrm{GeBr}_{4}$ and charge transfer from HOMO of $\mathrm{Zn}$-TPP to LUMO of $\mathrm{C}_{60}$ in the active layer.
\end{abstract}

Keywords: porphyrin; fullerene; organic solar cell; X-ray diffraction; transmission electron microscopy

\section{Introduction}

Electronic applications including electronic devices and solar cell systems based on organic semiconductor of fullerenes as electron accepting material at physical-solid-state have been developed [1-11]. For instance, photovoltaic properties of vapor deposited solar cells using bulk heterojunction film of fullerenes/phthalocyanine have been characterized in regard to light-induced 
charge separation and photo current behavior [12]. Electronic conductor and optical device of photoactive layer based on porphyrin derivatives have been developed [13-15]. Molecular design and morphological structure of porphyrin is important to control electronic structure with energy levels at highest occupied molecular orbital (HOMO) and lowest unoccupied molecular orbital (LUMO) [16,17]. Donor activity of modified porphyrin in dye-sensitized solar cells is suggested to be one of the key factors in optimizing electronic structure, photovoltaic and optical properties. The effects of the additive in the ternary porphyrin blends on solid-state polymer/fullerene bulk heterojunction solar cells have been focused on improving the photovoltaic performance [18]. The effects of an additive solvent and diiodooctane on the aggregation of a high-efficiency donor polymer and an acceptor molecule of fullerene derivatives have been investigated [19-22]. In addition, the hybrid bulk heterojunction organic solar cells of CdSe-fullerene $\left(\mathrm{C}_{60}\right)$ composite films with insert of quantum dot have been studied for harvesting lighted-excited electrons in the active layer [23]. The quantum dot of CdSe, $\mathrm{PbSe}$ and $\mathrm{PbS}$ nanocrystal has advantage to promote multiple light-induced charge carriers with high energy excitations in a wide range of optical absorption [24-28]. In a previous work, fabrication and characterization of bulk heterojunction of 5,10,15,20-tetraphenyl-21H,23H-porphyrin zinc (Zn-TPP) and $\mathrm{C}_{60}$ has been studied [29]. The light-induced charge separation and charge transfer has been investigated by current density and optical absorption. Copper phthalocyanine/fullerene-based solar cells were also fabricated, and the electronic and optical properties were investigated [30]. Effects of germanium addition to the solar cells were also investigated, which resulted in an increase of power conversion efficiencies of the solar cells. Nanostructures of the solar cells were investigated by transmission electron microscopy and electron diffraction, which indicated formation of germanium compound nanoparticles in the copper phthalocyanine layers. Nanodiamond-based solar cells were fabricated and the photovoltaic properties were investigated [31]. The nanostructures of the solar cells were investigated by transmission electron microscopy and X-ray diffractometry, and the electronic property was discussed.

The purpose of this present paper is to investigate additive effect of germanium tetrabromide $\left(\mathrm{GeBr}_{4}\right)$ on the photovoltaic properties of the $\mathrm{Zn}-\mathrm{TPP} / \mathrm{C}_{60}$ bulk heterojunction solar cells. The relationship between the photovoltaic properties and microstructure on the bulk heterojunction solar cells with insertion of $\mathrm{GeBr}_{4}$ into the active layers has been focused on optimization of the photovoltaic performance. The photovoltaic mechanism will be discussed by experimental results.

\section{Experimental Section}

Fullerene $\left(\mathrm{C}_{60}\right.$, Material Technologies Research, 99.98\%), 5,10,15,20-tetraphenyl-21H,23H-porphyrin zinc (Zn-TPP, Sigma-Aldrich Japan KK, Tokyo, Japan) were used as received. A mixture of $\mathrm{C}_{60}$ and Zn-TPP (10 mg) varied with weight ratio with $\mathrm{GeBr}_{4}\left(5 \times 10^{-3} \mathrm{~mL}\right.$, Sigma-Aldrich Japan KK, Tokyo, Japan) dissolved in o-dichlorobenzene (1 mL, Sigma-Aldrich Japan KK, Tokyo, Japan) was spin-coated on ITO (A11DU80, AGC Fabritech Co. Ltd., $10 \Omega$ /sq., Tokyo, Japan). The thickness of the bulk heterojunction films was approximately $150 \mathrm{~nm}$. The heterojunction film was prepared by vapor deposition process using diffusion vacuum pump $\left(10^{-3} \mathrm{~Pa}\right.$, ULVAC Inc., Tokyo, Japan). Heat treatment of these films on the ITO substrate was carried out at $100{ }^{\circ} \mathrm{C}$ for $30 \mathrm{~min}$ in $\mathrm{N}_{2}$ atmosphere, aluminum (Al) metal with a thickness of $100 \mathrm{~nm}$ was evaporated on a top of electrode. Figure 1 shows 
schematic diagram of the present $\mathrm{C}_{60} / \mathrm{Zn}$-TPP solar cells as (a) the bulk heterojunction and (b) heterojunction films. Light and dark current density voltage (J-V) characteristics (Hokuto Denko Corp., HSV-100, Kanagawa, Japan) of the solar cells were measured under AM $1.5\left(100 \mathrm{~mW} \mathrm{~cm}^{-2}\right)$ irradiation (Sanei Electric, XES-301S, Tokyo, Japan) in $\mathrm{N}_{2}$ atmosphere. Optical properties of the bulk heterojunction film of $\mathrm{C}_{60} / \mathrm{Zn}$-TPP at solid state were measured by UV-vis spectroscopy (Hitachi U-4100, Tokyo, Japan) and fluorescence photo spectrometer (F-4500 Hitachi, Tokyo, Japan). Internal microstructure was observed by transmission electron microscope (TEM, $200 \mathrm{kV}$, Hitachi H-8100, Tokyo, Japan) with electron diffraction. TEM is a useful method for nanostructure analysis. The polycrystal structure in the bulk heterojunction film was measured by thin X-ray reflection patterns (X'Pert-MPD system Philips Co. Ltd., Eindhoven, The Netherlands) using CuK $\alpha$ radiation. The chemical structures were optimized by CS Chem3D (Cambridge Soft, PerkinElmer Inc., Boston, MA, USA). Molecular orbital calculations were carried out by MOPAC (Fujitsu Ltd., Tokyo, Japan). In addition, the isolated molecular structures were optimized by quantum calculation using spin-restricted Hartree-Fock method (RHF) using 6-31G* as basis set (Gaussian 03, Gaussian Inc., Pittsburgh, PA, USA). The electronic structures of electron densities with energy levels at HOMO and LUMO were investigated.

Figure 1. Structure of bulk heterojunction solar cells.

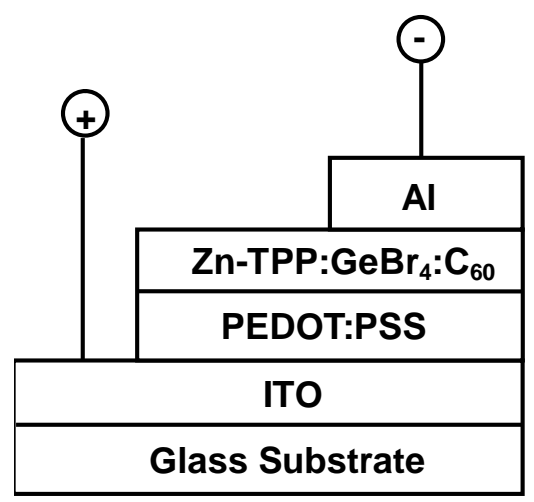

\section{Results and Discussion}

Dark and light induced current density-voltage (J-V) characteristics of the bulk heterojunction solar cells with weight ratio of $\mathrm{Zn}$-TPP and $\mathrm{C}_{60}$ with $\mathrm{GeBr}_{4}$ were investigated. The dark J-V curve displayed a gradual increase of current for positive bias to the $\mathrm{Zn}$-TPP electrode. This behavior indicates a light-induced charge separation with charge-transfer at the interface. Table 1 lists measured parameters on the bulk heterojunction solar cell varied with weight ratio of $\mathrm{Zn}-\mathrm{TPP} / \mathrm{C}_{60}$ to $\mathrm{GeBr}_{4}$.

Table 1. Measured parameters on bulk heterojunction solar cells of $\mathrm{Zn}-\mathrm{TPP} / \mathrm{C}_{60}$ with $\mathrm{GeBr}_{4}$.

\begin{tabular}{|c|c|c|c|c|}
\hline Zn-TPP:C $\mathrm{C}_{60}$ & $\eta(\%)$ & FF & $\mathbf{V}_{\text {oc }}(\mathbf{V})$ & $\mathbf{J}_{\mathrm{sc}}\left(\mathrm{mA} \mathrm{cm} \mathrm{cm}^{-2}\right)$ \\
\hline $3: 7$ & $2.2 \times 10^{-5}$ & 0.23 & 0.058 & 0.0017 \\
\hline $2: 8$ & $9.5 \times 10^{-4}$ & 0.20 & 0.25 & 0.019 \\
\hline $1: 9$ & $1.3 \times 10^{-2}$ & 0.29 & 0.26 & 0.17 \\
\hline \multicolumn{5}{|l|}{ Additive-free } \\
\hline $1: 9$ & $6.4 \times 10^{-3}$ & 0.20 & 0.23 & 0.14 \\
\hline
\end{tabular}


At weight ratio of $\mathrm{Zn}$-TPP to $\mathrm{C}_{60}$ of $3: 7$ by adding $\mathrm{GeBr}_{4}, \mathrm{~V}_{\mathrm{oc}}, \mathrm{J}_{\mathrm{sc}}, \mathrm{FF}$, and $\eta$ were obtained to be $0.058 \mathrm{~V}, 0.0017 \mathrm{~mA} \mathrm{~cm}{ }^{-2}, 0.23$ and $2.2 \times 10^{-5} \%$, respectively. The photovoltaic performance including the measured parameters was gradually improved with increasing weight ratio of $\mathrm{C}_{60}$ in $\mathrm{Zn}-\mathrm{TPP} / \mathrm{C}_{60}$ by adding $\mathrm{GeBr}_{4}$. At weight ratio of $\mathrm{Zn}-\mathrm{TPP} / \mathrm{C}_{60}$ in $1: 9$, the solar cells performance regarded $\mathrm{V}_{\mathrm{oc}}, \mathrm{J}_{\mathrm{sc}}$, and $\mathrm{FF}$ at $0.26 \mathrm{~V}, 0.17 \mathrm{~mA} \mathrm{~cm}^{-2}$ and 0.29 , which could estimate to be conversion efficiency of $1.3 \times 10^{-2} \%$. As reference case at weight ratio in $1: 9$ without addition of $\mathrm{GeBr}_{4}$, the measured parameters, $\mathrm{V}_{\mathrm{oc}}, \mathrm{J}_{\mathrm{sc}}, \mathrm{FF}$, and $\eta$ were obtained to be $0.23 \mathrm{~V}, 0.14 \mathrm{~mA} \mathrm{~cm}{ }^{-2}, 0.20$ and $6.4 \times 10^{-3} \%$, respectively. Additionally, quantitative analysis of variable amount of $\mathrm{GeBr}_{4}$ was performed on the bulk heterojunction solar cell at weight ratio of $\mathrm{Zn}-\mathrm{TPP} / \mathrm{C}_{60}$ in 1:9. At a fixed amount of $\mathrm{GeBr}_{4}$ in $0.025 \mathrm{~mL}$, the photovoltaic parameters, $\mathrm{V}_{\mathrm{oc}}, \mathrm{J}_{\mathrm{sc}}, \mathrm{FF}$, and $\eta$ were obtained to be $0.0013 \mathrm{~V}$, $0.0004 \mathrm{~mA} \mathrm{~cm}{ }^{-2}, 0.25$ and $1.3 \times 10^{-7} \%$. The exceed addition reduced the photovoltaic performance. The condition of $\mathrm{Zn}-\mathrm{TPP} / \mathrm{C}_{60}$ at weight ratio in $1: 9$ with additive volume of $\mathrm{GeBr}_{4}$ in $0.005 \mathrm{~mL}$ optimized the photovoltaic performance. The photovoltaic properties were due to light-induced charge separation with charge-transfer from HOMO of $\mathrm{Zn}$-TPP to LUMO of $\mathrm{C}_{60}$ in the active layer with insert of $\mathrm{GeBr}_{4}$.

Optical absorptions of the bulk heterojunction solar cells at weight ratio of $\mathrm{Zn}-\mathrm{TPP} / \mathrm{C}_{60}$ in $1: 9$ with insert of $\mathrm{GeBr}_{4}$ in $0.005 \mathrm{~mL}$ are shown in Figure 2. The bulk heterojunction of $\mathrm{Zn}-\mathrm{TPP} / \mathrm{C}_{60}$ had a strong optical absorption in the range of $300 \mathrm{~nm}-1300 \mathrm{~nm}$. Especially, insertion of $\mathrm{GeBr}_{4}$ in the active layer improved the optical absorption in the range of $300 \mathrm{~nm}-500 \mathrm{~nm}$ and $800 \mathrm{~nm}-1000 \mathrm{~nm}$. The observed absorption at $350 \mathrm{~nm}, 480 \mathrm{~nm}$ to $1050 \mathrm{~nm}$ was converted to energy level of $3.5 \mathrm{eV}, 2.6 \mathrm{eV}$ and $1.2 \mathrm{eV}$, respectively. Enlargement of the optical absorption would be attributed from increase of the light-induced exciton in the active layer with insert of $\mathrm{GeBr}_{4}$.

Figure 2. UV-vis absorptions of bulk heterojunction thin films of tetraphenyl porphyrin zinc ( $\mathrm{Zn}$-TPP) and $\mathrm{C}_{60}$ at weight ratio of 1:9 with insert of $\mathrm{GeBr}_{4}$.

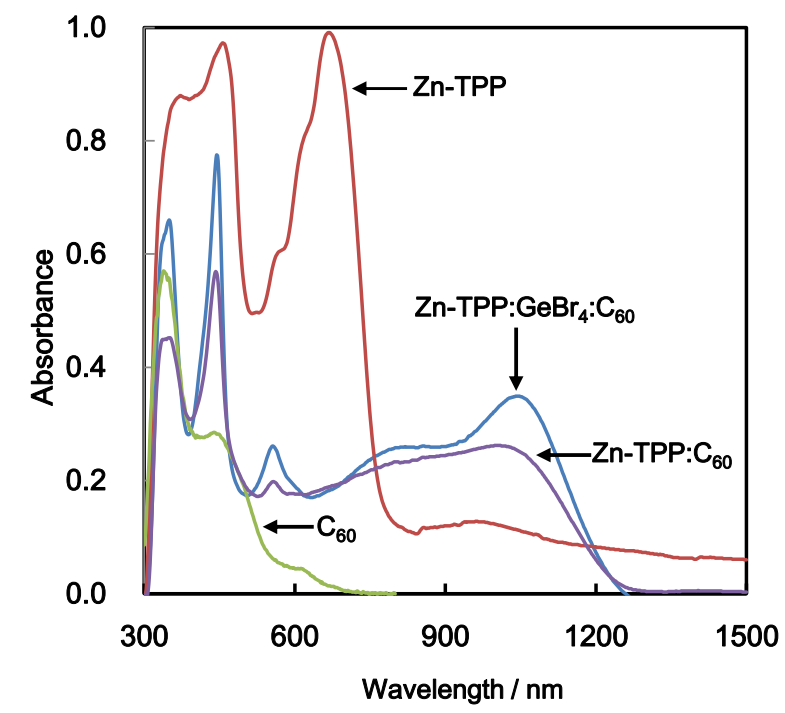

$\mathrm{X}$-ray diffractions of the bulk heterojunction film at weight ratio of $\mathrm{Zn}-\mathrm{TPP} / \mathrm{C}_{60}$ in 1:9 by adding $\mathrm{GeBr}_{4}$ on glass substrate are shown in Figure 3. The X-ray diffraction patterns displayed the crystal order of $\mathrm{C}_{60}$, which confirmed tetragonal system noted in crystal index, 111, 220, 311, 220, 420, 422 and 511 in a range of $10^{\circ}$ and $33^{\circ}$ in $2 \theta$. There existed a strong peak of Zn-TPP with a small peak at 
$5^{\circ}$ and $22^{\circ}$ in $2 \theta$. The diffraction patterns using the Sherrer's formula suggested that there were about $6 \mathrm{~nm}$ of particle sizes in the tetragonal system. The crystal growth of $\mathrm{C}_{60}$ was inhibited by insertion of the germanium bromide into the active layer. The germanium crystal was not confirmed around $2 \theta$ in the range of $25^{\circ}-50^{\circ}$ [32].

Figure 3. X-ray diffraction patterns of the bulk heterojunction thin films.

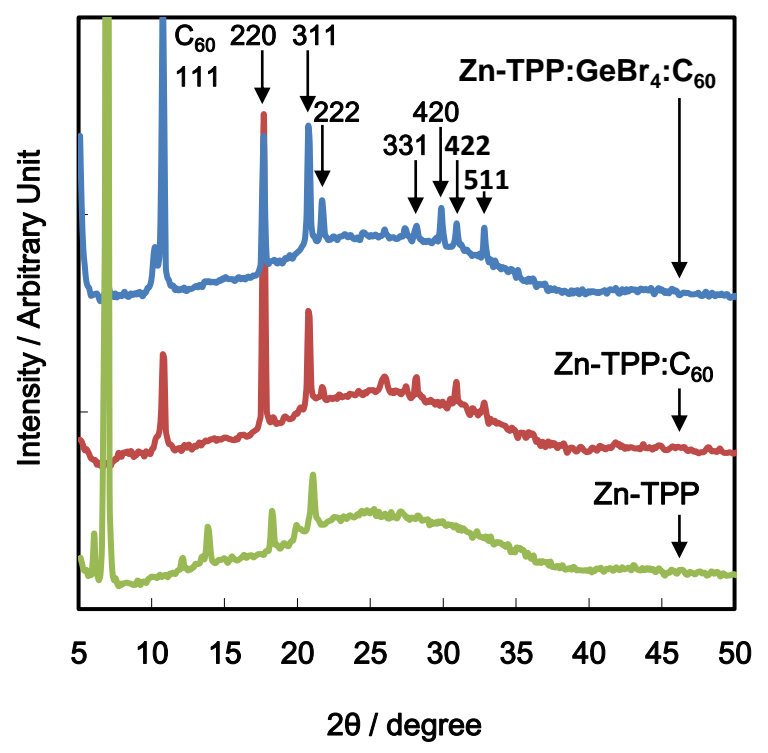

Figure 4. (a) TEM image and (b) electron diffraction pattern of the bulk heterojunction thin film.

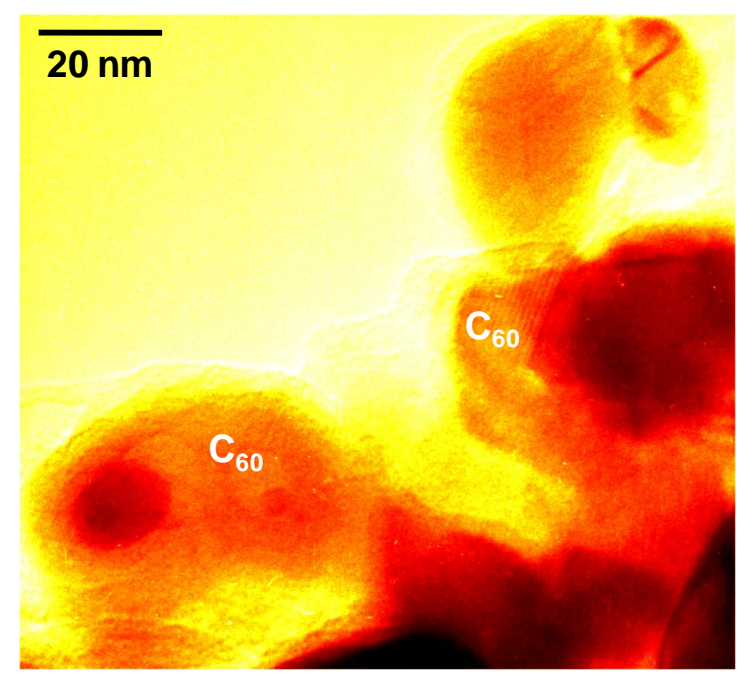

(a)

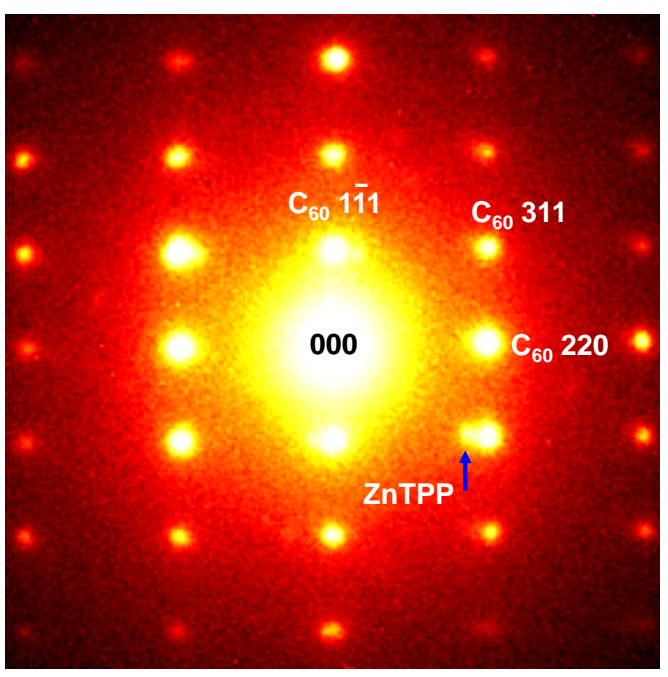

(b)

Figure 4 show (a) TEM image and (b) electron diffraction of the bulk heterojunction film at weight ratio of $1: 9$ with $\mathrm{GeBr}_{4}$. As shown in Figure $4 \mathrm{a}$, the molecules of $\mathrm{C}_{60}$ were coagulated with each other to form the particle as grain size in the range of $10 \mathrm{~nm}-20 \mathrm{~nm}$. The TEM image displayed the crystal lattice of $\mathrm{C}_{60}$ to be about $0.38 \mathrm{~nm}$ at 111 in crystal index as tetragonal phase in the polycrystal

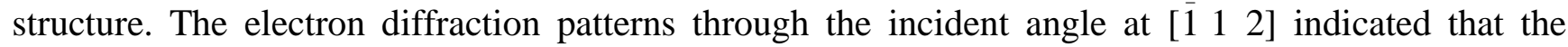
polycrystal coagulation of $\mathrm{C}_{60}$ had tetragonal structure as noted in crystal index at 111, 210 and 311 
with a strong spot as Zn-TPP. The amorphous coagulations were dispersed in the range of $18-30 \mathrm{~nm}$ as the particle size. The amorphous coagulations as intrinsic germanium compound appeared to be semi-conductive behavior with a narrow band-gap in the range of 0.8-2.2 eV [33] as shown in Figure 5.

As a reference case to support the experiment result, the coagulations of the germanium compound converted from germanium bromide saturated ionic liquid 1-butyl-3-methylimidazolium hexafluorophosphate on $\mathrm{Au}$ (111) has been studied with in-situ scanning tunneling microscopy [34]. The tunneling spectrum of an approximately $500 \mathrm{~nm}$ thick germanium compound film saturated ionic liquid on $\mathrm{Au}$ (111) suggested semiconductive behavior with a typical band gap of $0.7 \mathrm{eV}$, which made a good agreement with the value of $0.67 \mathrm{eV}$ for intrinsic coagulations of germanium compound.

In the presence work, insert of coagulations of germanium compound into the active layer improved the light-induced exciton with charge transfer near the interface in microstructure. In actual conditions, energy loss would be generated by the Schottky barrier at the interface between $\mathrm{Zn}-\mathrm{TPP}, \mathrm{C}_{60}$, and $\mathrm{GeBr}_{4}$ on $\mathrm{Al}$ substrate. The heat treatment of the internal microstructure near interface between the crystal phase of $\mathrm{C}_{60}$ and $\mathrm{Zn}$-TPP with insert of $\mathrm{GeBr}_{4}$ will guide a considerable support to inhibit recombination between electrons and holes, which will improve the photovoltaic performance with increasing $\mathrm{J}_{\mathrm{sc}}$ and $\eta$ in the $\mathrm{J}-\mathrm{V}$ curve.

Figure 5. Energy level diagram of the bulk heterojunction solar cell.

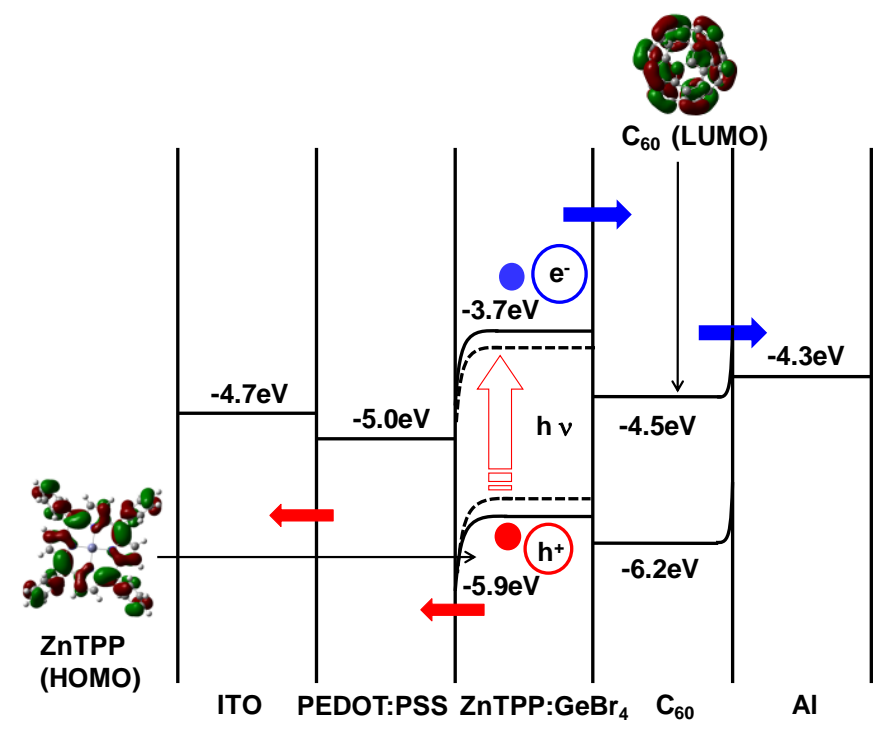

The photovoltaic mechanism of the bulk heterojunction solar cells was discussed by the experimental results. Schematic energy diagrams of the present solar cells with energy levels were summarized as shown in Figure 5. The photovoltaic mechanism of the present solar cells was discussed as follows. The light irradiation immediately generated charge-separation with a band gap between HOMO of Zn-TPP and LUMO of $\mathrm{C}_{60}$ with insert of $\mathrm{GeBr}_{4}$. The electrons were excited at a conductive bond, and holes generated at valence band. Suddenly, the excited electrons of Zn-TPP were injected from the conductive band to that of $\mathrm{C}_{60}$ at the crystal phase. In addition, the bulk heterojunction solar cell at an excess amount of $\mathrm{C}_{60}$ showed improvement in the light-induced exciton with an insert of $\mathrm{GeBr}_{4}$ and the electron diffusion without trapping at interface between inner regions near interface, which suggested an increase of $\mathbf{J}_{\mathrm{sc}}$ related to carrier mobility, as a result of increasing 
the conversion efficiency. In contrast, the holes of $\mathrm{Zn}$-TPP at the valence band suddenly charge-transferred to PEDOT:PSS on electrolyte. $V_{\text {oc }}$ of the solar cells were related with an energy gap between HOMO of Zn-TPP and LUMO of $\mathrm{C}_{60}$ narrowed with an insert of $\mathrm{GeBr}_{4}$. Controlling the electronic structure and the energy gap between HOMO and LUMO is an important factor for improving the photovoltaic performance with the conversion efficiency. Recently, electronic structures with the energy gap between HOMO and LUMO have been studied by quantum chemical calculation using DFT [16,17].

In this present work, the electronic structures of Zn-TPP with the HOMO-LUMO gap were calculated by DFT. The molecular orbital of Zn-TPP and $\mathrm{C}_{60}$ at HOMO, LUMO with the energy levels are shown in Figure 5. Modified porphyrin derivatives combined with phenyl group as electron-donating affinity suggests uniformity on electron density distribution, which becomes a strong donor as p-type semiconductor with a narrow band gap of energy level between HOMO and LUMO. The strong affinity to accept substitutions with a low distribution of electron density in the aromatic ring would support the use of an electron acceptor as n-type semiconductor. The chemical modification of porphyrin has a great advantage to generate light-induced charge separation, suggesting improvement of the photovoltaic performance. Improvement of internal structure would promote injection of electron excitation near interface between $\mathrm{Zn}$-TPP and $\mathrm{C}_{60}$ in the internal microstructure. The heat treatment of the microstructure would recover the light-induced charge separation, and then the extent of carrier diffusion, which would result in an improvement of the photovoltaic performance. Additionally, insertion of the semi-conductive coagulations based on germanium compound into the active layer would support the promotion of excitation under the Plasmon field effect.

As an advantage, the coagulations with semi-conductive particles of germanium compound converted from $\mathrm{GeBr}_{4}$ had strong absorption with a low-wave length for improvement of photovoltaic performance. In order to incorporate the coagulations with the semi-conductive particles in the active layer, organic solvent with the coagulations of the particles needs to be used in the manufacturing process. For instance, $\mathrm{GeBr}_{4}$ has melting point at $26.1^{\circ} \mathrm{C}$. The material shows melting characteristics at $30{ }^{\circ} \mathrm{C}$ above the melting point and easily dissolves in organic solvent. The material has an advantage when used in dispersion in the organic active layer. By annealing treatment, $\mathrm{Ge}_{3} \mathrm{Br}_{4}$ was de-composited with removing bromine atom to form the coagulations of the particles under device fabrication condition. The coagulations of amorphous germanium compound into the active layer were dispersed in a range of $20-30 \mathrm{~nm}$ in the size. Addition of the coagulations into the active layer had a positive effect on the photovoltaic and optical properties.

Several points of view from cost, toxicity and hazard will be discussed regarding the use of organic solar cells. Additives of $\mathrm{GeBr}_{4}$ have slightly higher cost associated with their industrial application. If mass production using organic layer with $\mathrm{GeBr}_{4}$ is used for applying the organic solar cell, the production cost and price will be reduced in practical use. In the toxicity and hazard points, organic active layer including a large amount of $\mathrm{GeBr}_{4}$ will cause hydrolysis reaction and inflammation on mucosal tissues. However, the experimental condition with a small amount of the coagulations of the particles converted from $\mathrm{GeBr}_{4}$ will be applied for developing safe devices. The organic active layer including the coagulations of the semi-conductive particles had an advantage in improvement of the photovoltaic performance. The photovoltaic mechanism of the solar cells was discussed by experimental results. The photovoltaic performance was originated in the light-induced carrier 
separation promoted by insert of $\mathrm{GeBr}_{4}$ and charge transfer from $\mathrm{HOMO}$ of $\mathrm{Zn}$-TPP to LUMO of $\mathrm{C}_{60}$ in the active layer. Instead of inserting the coagulations of the particles, organic solvent with incorporation of silicon compounds and polysilane derivatives will be used for fabrication of an organic solar cell.

\section{Conclusions}

The effects of germanium tetrabromide addition to $\mathrm{Zn}-\mathrm{TPP} / \mathrm{C}_{60}$ bulk heterojunction organic solar cells were characterized. The light-induced charge separation with charge transfer was investigated by current density and optical absorption. Addition of $\mathrm{GeBr}_{4}$ into active layer of $\mathrm{Zn}-\mathrm{TPP} / \mathrm{C}_{60}$ had a positive effect on the photovoltaic and optical properties. The TEM image, X-ray and electron diffraction patterns showed the crystal lattice of $\mathrm{C}_{60}$ to be about $0.38 \mathrm{~nm}$ at 111 in crystal index at the tetragonal phase with a strong spot as crystal structure of Zn-TPP. The coagulations of amorphous germanium compound into the active layer were dispersed in a range of 20-30 nm in size. Addition of the coagulations into the active layer had a positive effect on the photovoltaic and optical properties. The photovoltaic mechanism of the solar cells was discussed by experimental results. The photovoltaic performance was due to the light-induced carrier separation promoted by insert of $\mathrm{GeBr}_{4}$ and charge transfer from HOMO of Zn-TPP to LUMO of $\mathrm{C}_{60}$ in the active layer.

\section{Conflicts of Interest}

The authors declare no conflict of interest.

\section{References}

1. Kroto, H.W.; Heath, J.R.; O’Brien, S.C.; Curl, R.F.; Smalley, R.E. C60: Buckminsterfullerene. Nature 1985, 318, 162-163.

2. Steven, C.E.; Warren, E.P. Theoretical Fermi-Surface Properties and Superconducting Parameters for $\mathrm{K}_{3} \mathrm{C}_{60}$. Science 1991, 254, 842-845.

3. Allemand, P.-M.; Khemani, K.C.; Koch, A.; Wudl, F.; Holczer, K.; Donovan, S.; Gruner, G.; Thompson, J.D. Organic Molecular Soft Ferromagnetism in a Fullerene $\mathrm{C}_{60}$. Science 1991, 253, 301-302.

4. Mihailovic, D.; Arcon, D.; Venturini, P.; Blinc, R.; Omerzu, A.; Cevc, P. Orientational and Magnetic Ordering of Buckyballs in TDAE- $\mathrm{C}_{60}$. Science 1995, 268, 400-402.

5. Lappas, A.; Prassides, K.; Vavekis, K.; Arcon, D.; Blinc, R.; Cevc, P.; Amato, A.; Feyerherm, R.; Gygax, F.N.; Schenck, A. Spontaneous Magnetic Ordering in the Fullerene Charge-Transfer Salt (TDAE)C $\mathrm{C}_{60}$. Science 1995, 267, 1799-1802.

6. Khlyabich, P.P.; Burkhart, B.; Rudenko, A.E.; Barry, C. Optimization and Simplification of Polymer-Fullerene Solar Cells through Polymer and Active Layer Design. Polymer 2013, 54, 5267-5298.

7. Marrocchi, A.; Lanari, D.; Facchettibc, A.; Vaccaro, L. Poly(3-hexylthiophene): Synthetic Methodologies and Properties in Bulk Heterojunction Solar Cells. Energy Environ. Sci. 2012, 5, 8457-8474. 
8. Roncali, J. Single Material Solar Cells: The Next Frontier for Organic Photovoltaics? Adv. Energy Mater. 2011, 1, 147-160.

9. Brabec, C.J.; Gowrisanker, S.; Halls, J.J.M.; Laird, D.; Jia, S.; Williams, S.P. Polymer-Fullerene Bulk-Heterojunction Solar Cells. Adv. Mater. 2010, 22, 3839-3856.

10. Liao, H.C.; Tsao, C.S.; Lin, T.H.; Jao, M.H.; Chuang, C.M.; Chang, S.Y.; Huang, Y.C.; Shao, Y.T.; Chen, C.Y.; Su, C.J.; et al. Nanoparticle-Tuned Self-Organization of a Bulk Heterojunction Hybrid Solar Cell with Enhanced Performance. ACS Nano 2012, 6, 1657-1666.

11. Chen, W.; Xu, T.; He, F.; Wang, W.; Wang, C.; Strzalka, J.; Liu, Y.; Wen, J.; Miller, D.J.; Chen, J.; et al. Hierarchical Nanomorphologies Promote Exciton Dissociation in Polymer/Fullerene Bulk Heterojunction Solar Cells. Nano Lett. 2011, 11, 3707-3713.

12. Brousse, B.; Ratier, B.; Moliton, A. Vapor deposited solar cells based on heterojunction or interpenetrating networks of zinc phthalocyanine and $\mathrm{C}_{60}$. Thin Solid Films 2004, 451-452, 81-85.

13. Donzello, M.P.; Ercolani, C.; Kadish, K.M.; Ricciardi, G.; Rosa, A.; Stuzhin, P.A. Tetrakis (thiadiazole)porphyrazines. 5. Electrochemical and DFT/TDDFT studies of the free-base macrocycle and its $\mathrm{Mg}^{\mathrm{II}}, \mathrm{Zn}^{\mathrm{II}}$, and $\mathrm{Cu}^{\mathrm{II}}$ complexes. Inorg. Chem. 2007, 46, 4145-4157.

14. David, C.; Hans, G.; Mathieu, O.; Jef, P.; Paul, H. Stacked organic solar cells based on pentacene and $\mathrm{C}_{60}$. Solar Energy Mater. Solar Cells 2007, 91, 399-404.

15. Mauro, M.; Matthias, W.; Alberta, B.; Nikos, K.; Sean, S.; Markus, S.; Zhengguo, Z.; David, W.; Russell, G.; Christoph, B. Bipolar Charge Transport in PCPDTBT-PCBM Bulk-Heterojunctions for Photovoltaic Applications. Adv. Funct. Mater. 2008, 18, 1757-1766.

16. Park, J.K.; Lee, H.R.; Chen, J.; Shinokubo, H.; Osuka, A.; Kim, D. Photoelectrochemical Properties of Doubly $\beta$-Functionalized Porphyrin Sensitizers for Dye-Sensitized Nanocrystalline-TiO 2 Solar Cells. J. Phys. Chem. C 2008, 112, 16691-16699.

17. Ruimin, M.; Ping, G.; Linlin, Y.; Lianshun, G.; Xianxi, Z.; Mohammad, K.N.; Michael, G. Theoretical Screening of $-\mathrm{NH}_{2}-,-\mathrm{OH}-,-\mathrm{CH}_{3^{-}},-\mathrm{F}-$, and -SH-Substituted Porphyrins As Sensitizer Candidates for Dye-Sensitized Solar Cells. J. Phys. Chem. A 2010, 114, 1973-1979.

18. Dastoor, P.C.; McNeill, C.R.; Frohne, H.; Foster, C.J.; Dean, B.; Fell, C.J.; Belcher, W.J.; Campbell, W.M.; Officer, D.L.; Blake, I.M.; et al. Understanding and Improving Solid-State Polymer/C 60 -Fullerene Bulk-Heterojunction Solar Cells Using Ternary Porphyrin Blends. J. Phys. Chem. C 2007, 111, 15415-15426.

19. Chen, F.C.; Tseng, H.C.; Ko, C.J. Solvent mixtures for improving device efficiency of polymer photovoltaic devices. Appl. Phys. Lett. 2008, 92, 103316.

20. Lou, S.J.; Szarko, J.M.; Xu, T.; Yu, L.; Marks, T.J.; Chen, L.X. Effects of Additives on the Morphology of Solution Phase Aggregates Formed by Active Layer Components of High-Efficiency Organic Solar Cells. J. Am. Chem. Soc. 2011, 133, 20661-20663.

21. Freitas, J.N.D.; Nogueira, A.F. Incorporation of Inorganic Nanoparticles into Bulk Heterojunction Organic Solar Cells. Nanoenergy 2013, doi:10.1007/978-3-642-31736-1_1.

22. Lua, A.J.; Beaupréb, S.; Leclercb, M.; Taoa, Y. Control of the active layer nanomorphology by using co-additives towards high-performance bulk heterojunction solar cells. Org. Electron. 2012 , $13,1736-1741$. 
23. Patrick, B.; Prashant, V.K. Quantum Dot Solar Cells. Electrophoretic Deposition of CdSe-C 60 Composite Films and Capture of Photogenerated Electrons with $\mathrm{nC}_{60}$ Cluster Shell. J. Am. Chem. Soc. 2008, 130, 8890-8891.

24. Nozik, A.J. Quantum dot solar cells. Physica E 2002, 14, 115-120.

25. Istvan, R.; Vaidyanathan, S.; Masaru, K.; Prashant, V.K. Quantum Dot Solar Cells. Harvesting Light Energy with CdSe Nanocrystals Molecularly Linked to Mesoscopic $\mathrm{TiO}_{2}$ Films. J. Am. Chem. Soc. 2006, 128, 2385-2393.

26. Richard, D.S.; Vladimir, M.A.; Victor, C.K. High-efficiency carrier multiplication through direct photogeneration of multi-excitons via virtual single-exciton states. Nat. Phys. 2005, 1, 189-194.

27. Randy, J.E.; Matthew, C.B.; Justin, C.J.; Pingrong, Y.; Olga, I.M.; Arthur, J.N.; Andrew, S.; Alexander, L.E. Highly efficient multiple exciton generation in colloidal $\mathrm{PbSe}$ and $\mathrm{PbS}$ quantum dots. Nano Lett. 2005, 5, 865-871.

28. Luque, A.; Martí, A.; López, N.; Antolín, E.; Cánovas, E.; Stanley, C.; Farmer, C.; Caballero, L.J.; Cuadra, L.; Balenzategui, J.L. Experimental analysis of the quasi-Fermi level split in quantum dot intermediate-band solar cells. Appl. Phys. Lett. 2005, 87, 083505:1-083505:3.

29. Oku, T.; Noma, T.; Suzuki, A.; Kikuchi, K.; Kikuchi, S. Fabrication and characterization of fullerene/porphyrin bulk heterojunction solar cells. J. Phys. Chem. Solid. 2010, 71, 551-555.

30. Oku, T.; Kumada, K.; Suzuki; A.; Kikuchi, K. Effects of germanium addition to copper phthalocyanine/fullerene-based solar cells. Cent. Eur. J. Eng. 2012, 2, 248-252.

31. Nagata, A.; Oku, T.; Kikuchi, K.; Suzuki, A.; Yamasaki, Y.; Osawa, E. Fabrication, nanostructures and electronic properties of nanodiamond-based solar cells. Prog. Nat. Sci. 2010, 20, 38-42.

32. Vijayarangamuthu, K.; Rath, S.; Kabiraj, D.; Avasthi, D.K.; Kulriya, P.K.; Singh, V.N.; Mehta, B.R. Ge nanocrystals embedded in $\mathrm{GeO}_{x}$ matrix formed by thermally annealing of $\mathrm{Ge}$ oxide films. J. Vac. Sci. Technol. A 2009, 27, 731-733.

33. Ardyanian, M.; Rinnert, H.; Vergnat, M. Structure and photoluminescence properties of evaporated $\mathrm{GeO}_{x} / \mathrm{SiO}_{2}$ multilayers. J. App. Phys. 2006, 100, 113106:1-113106:4.

34. Frank, E.; Sherif, Z.E.A. Nanoscale electrodeposition of germanium on Au (111) from an ionic liquid: An in situ STM study of phase formation Part I. Ge from $\mathrm{GeBr}_{4}$. Phys. Chem. Chem. Phys. 2002, 4, 1640-1648.

(C) 2014 by the authors; licensee MDPI, Basel, Switzerland. This article is an open access article distributed under the terms and conditions of the Creative Commons Attribution license (http://creativecommons.org/licenses/by/3.0/). 